\title{
Grubbing by wild boars (Sus scrofa L.) and its impact on hardwood forest soil carbon dioxide emissions in Switzerland
}

\author{
Anita C. Risch · Sven Wirthner • Matt D. Busse • \\ Deborah S. Page-Dumroese $\cdot$ Martin Schütz
}

Received: 20 January 2009 / Accepted: 11 May 2010 / Published online: 30 May 2010

(C) Springer-Verlag 2010

\begin{abstract}
Interest in soil $\mathrm{C}$ storage and release has increased in recent years. In addition to factors such as climate/land-use change, vertebrate animals can have a considerable impact on soil $\mathrm{CO}_{2}$ emissions. To date, most research has considered herbivores, while the impact of omnivorous animals has rarely been investigated. Our goal was to determine how European wild boars (Sus scrofa L.), large omnivores that consume soil-inhabiting animals and belowground plant parts by grubbing in the soil, affect soil $\mathrm{C}$ dynamics. We measured soil respiration $\left(\mathrm{CO}_{2}\right)$, temperature, and moisture on paired grubbed and non-grubbed plots in six hardwood forest stands for a 3-year period and sampled fine root and microbial biomass at the beginning and after 2 years of the study. We also measured the percentage of freshly disturbed forest soil within the larger surround-
\end{abstract}

Communicated by Manuel Lerdau.

A. C. Risch $(\bowtie) \cdot$ S. Wirthner

Research Unit Community Ecology, Animal Ecology,

Swiss Federal Institute for Forest, Snow and Landscape Research,

Zuercherstrasse 111, 8903 Birmensdorf, Switzerland

e-mail: anita.risch@wsl.ch

M. D. Busse

Pacific Southwest Research Station, USDA Forest Service, 3644 Avtech Parkway, Redding, CA 96002, USA

D. S. Page-Dumroese

Rocky Mountain Research Station, USDA Forest Service,

1221 South Main Street, Moscow, ID 83843, USA

M. Schütz

Research Unit Community Ecology, Vegetation Ecology, Swiss Federal Institute for Forest, Snow and Landscape Research, Zuercherstrasse 111, 8903 Birmensdorf, Switzerland ings of each stand and used this information together with hunting statistics and forest cover data to model the total amount of $\mathrm{CO}_{2}$ released from Swiss forest soils due to grubbing during 1 year. Soil $\mathrm{CO}_{2}$ emissions were significantly higher on grubbed compared to non-grubbed plots during the study. On average $23.1 \%$ more $\mathrm{CO}_{2}$ was released from these plots, which we associated with potential alterations in $\mathrm{CO}_{2}$ diffusion rates, incorporation of litter into the mineral soil and higher fine root/microbial biomass. Thus, wild boars considerably increased the small-scale heterogeneity of soil properties. Roughly $1 \%$ of Switzerland's surface area is similar to our sites (boar density/forest cover). Given the range of forest soil disturbance of $27-54 \%$ at our sites, the geographic information system model predicted that boar grubbing would lead to the release of an additional 49,731.10-98,454.74 t CO year $^{-1}$. These values are relatively small compared to total soil emissions estimated for Swiss hardwood forests and suggest that boars will have little effect on large-scale emissions unless their numbers increase and their range expands dramatically.

Keywords Soil mixing - Microbial biomass . Fine root biomass $\cdot$ Omnivore $\cdot$ Geographic information system model

\section{Introduction}

Soils are an important component of the global $\mathrm{C}$ cycle because they store over two-thirds of the $\mathrm{C}$ of terrestrial ecosystems (Schulze 2006). Consequently, interest in understanding the factors that control this pool is high. Mineral soil $\mathrm{C}$ turnover rates and, therefore, the amount of $\mathrm{CO}_{2}$ and other greenhouse gases released from the soil to the atmosphere, have been shown to be a function of soil: 
(1) organic matter quality and quantity; (2) micro-climate (temperature, moisture); (3) physical properties (texture, bulk density); (4) chemical properties ( $\mathrm{pH}, \mathrm{C} /$ nutrient concentrations); and (5) biological properties (microbial biomass, composition, diversity, activity; e.g., Kirschbaum 1995; Lomander et al. 1998; Epstein et al. 2002). Thus, any alteration of one or several of those parameters can increase or decrease soil $\mathrm{CO}_{2}$ emission and organic matter decomposition rates, and the subsequent total $\mathrm{C}$ stored in soil.

Vertebrate animals can directly or indirectly alter soil biotic and abiotic properties (see e.g., reviews by Jefferies et al. 1994; Bardgett and Wardle 2003; Wardle et al. 2004; Pastor et al. 2006). By foraging on plant material they can induce changes in plant properties ( $\mathrm{C}$ exudation, tissue nutrient content, plant community composition and productivity) and indirectly affect soil physical, chemical and biological properties as well as alter the quality and quantity of organic matter that enters the soil (see e.g., Bardgett and Wardle 2003; Pastor et al. 2006). Additionally, they can directly affect soil biotic and abiotic properties through physical disturbance (e.g., Tardiff and Stanford 1998; Van der Wal et al. 2007), by returning nutrients to the soil through waste (urine, feces) or carcasses (e.g., Carter et al. 2007; Fornara and Du Toit 2008), and by altering the belowground community composition of microbes, invertebrates, and vertebrates through consumption (e.g., Russell and Detling 2003; Mohr et al. 2005). As a consequence, animals are likely to have a strong effect on the amount of $\mathrm{C}$ released from the soil as $\mathrm{CO}_{2}$.

Most field studies on vertebrate-soil $\mathrm{CO}_{2}$ interactions have been conducted in ecosystems inhabited by domestic (e.g., Morris and Jensen 1998; Rochette et al. 2000; Bremer and Ham 2002; Owensby et al. 2006; Jia et al. 2007), and to a lesser extent, native herbivores (e.g., Bremer et al. 1998; Knapp et al. 1998; Johnson and Matchett 2001; Risch and Frank 2006; Van der Wal et al. 2007). In contrast, surprisingly little research has focused on how omnivorous vertebrates (consuming both plants and prey) affect soil properties and subsequent $\mathrm{CO}_{2}$ emissions. Although these animals consume less aboveground plant material compared to herbivores and have lower indirect effects on soil processes, they could potentially have a considerable direct effect on the soil system through: (1) the physical disturbance of the soil when searching for forage (turning over the soil or litter layer), and (2) the alterations of the belowground community when consuming belowground plant parts or animals.

Wild boars (Sus scrofa L.) are omnivorous animals that obtain a considerable proportion of their diet by grubbing in the soil searching for plant seeds, roots/bulbs, vertebrate and invertebrate animals (=rooting; Howe and Bratton 1976; Wood and Roark 1980; Bratton et al. 1982; Baber and Coblentz 1987; Hone 1988). Grubbing involves breaking through the vegetation and typically mixes the top 15$70 \mathrm{~cm}$ of the litter and mineral soil (Imeson 1977; Genov 1981; Kotanen 1995). Consequently, wild boars, like other bioturbators, strongly affect soil physical, chemical and biological properties (review in Gabet et al. 2003; Singer et al. 1984; Lacki and Lancia 1986; Groot Bruinderink and Hazebroek 1996; Moody and Jones 2000; Sierra 2001; Mohr et al. 2005), and have the potential to exert a considerable impact on the amount of $\mathrm{CO}_{2}$ released from the soil.

Wild boars are synanthropic species with a high reproductive potential, a high adaptability to a wide variety of habitats and a high ecological plasticity (Taylor et al. 1998). They naturally inhabited northern Africa, Europe and the whole of Asia, but also were introduced into the Americas, Australia and New Zealand. In many European countries, their population size has increased considerably during the past three decades and the boars have re-colonized regions where they were drastically reduced or locally extinct during the eighteenth and nineteenth century (Schley et al. 1998; Geisser and Reyer 2005; Hebeisen et al. 2007). Several factors are likely responsible for these changes in boar numbers and distributions: (1) higher frequency in mast years of beech and oak due to air pollution and environmental stress, (2) higher survival rates of piglets due to climate change-related increased temperatures during winter, (3) increased agricultural use of corn as a crop, (4) increased size of agricultural fields (less disturbance, lower detectability of boars), (5) trend in forest management towards replacing conifers with hardwoods, (6) baiting or diverting boars with corn feed by hunters and game managers, and (7) decreasing numbers or the elimination of natural predators (Feichtner 1998; Krüger 1998; Hespeler 2004; Melis et al. 2006). Today, European wild boar densities are estimated to range between 0.3 and 12.0 boars per $\mathrm{km}^{2}$ (Melis et al. 2006; Hebeisen et al. 2007). In Switzerland, the population size has been steadily increasing since the 1980s, but the animals mostly occur in the northernand southernmost areas of the country, where hardwood forests predominate.

The primary objective of our study is to assess how grubbing by wild boars affects soil $\mathrm{CO}_{2}$ emissions in hardwood forests in the Swiss central plateau. We measured soil $\mathrm{CO}_{2}$ emissions, soil temperature and soil moisture over 3 years as well as determined fine root and microbial biomass in grubbed and non-grubbed soil at the beginning and after 2 years of the study to assess the impact these animals have on those properties. Further, we estimated total percentage of freshly disturbed forest soil by boars in our different forest stands twice during the study and used this information together with Swiss wild boar hunting statistics and forest cover data to estimate the effect wild boars might have on soil $\mathrm{CO}_{2}$ emissions at the national scale using a geographic information system (GIS) model. 


\section{Materials and methods}

Study area and sampling design

The study was conducted in hardwood and mixed hardwood forests located north of Zurich $\left(47^{\circ} 23^{\prime} \mathrm{N}, 8^{\circ} 31^{\prime} \mathrm{E}\right)$ in the state of Zurich, Switzerland. The mean annual temperature is $9.2^{\circ} \mathrm{C}$, and the mean annual precipitation is $1,137 \mathrm{~mm}$ (30 years averages from 1978 to 2008) with roughly $25 \%$ falling as snow during the months of November up to and including February (MeteoSchweiz 2008). We selected six 5-ha sites in beech (Fagus sylvatica L.)dominated stands that also contained other hardwoods such as oaks (Quercus ssp.) and hornbeam (Carpinus betulus L.) and conifers [Norway spruce (Picea abies L. Karst); Scots pine (Pinus sylvestris L.)]. All sites were classified as typical Galio oderati-Fagetum following Keller et al. (1998) and were located within $50 \mathrm{~km}$ of each other. Elevation differences between our study sites did not exceed $120 \mathrm{~m}$. Soil physical and chemical properties were also similar among the sites (Table 1): The soil texture class was sandy loam underlain with sandstone parent material. The litter layer averaged $3 \mathrm{~cm}$, rock content was $33 \%$, and soil depths extended to $75 \mathrm{~cm}$. Soils on these study sites were highly acidic (all pHs $<4.0$ ).

Extensive grubbing events larger than $100 \mathrm{~m}^{2}$ in size originating from grubbing between October 2005 and February 2006 were detected at all sites in spring 2006. We established a paired plot design consisting of a grubbed (disturbed) and non-grubbed (undisturbed) plot $10 \times 10 \mathrm{~m}$ in size at each study site in late May 2006. The nongrubbed plot was randomly selected in close proximity to the grubbing incident, but located at least $15 \mathrm{~m}$ from the grubbed plot. Since grubbing generally is visible for roughly 3 years in the forests we worked in, our nongrubbed plots have, if ever, not been disturbed for 3 years. Both the grubbed and non-grubbed plots were fenced with 1.3-m-high knotted mesh (Ursus 130/11/15; mesh size at 0 - to 50 -cm height $=10 \times 15 \mathrm{~cm}$; mesh size at $50-110 \mathrm{~cm}=$ $15 \times 15 \mathrm{~cm}$; mesh size at $110-130 \mathrm{~cm}=20 \times 15 \mathrm{~cm}$;
Hortima, Hausen, Switzerland) tightened around 1.6-m square wooden posts $(15 \times 15 \mathrm{~cm})$ to prevent boars from entering. Two 2.5 -mm-diameter wires were affixed at 1.4- and $1.5-\mathrm{m}$ height to prevent animals (roe deer) from jumping over the $1.3-\mathrm{m}$ mesh.

To determine if boars specifically select foraging sites within a homogeneous stand or randomly grub in the soil, we established a third randomly chosen, non-grubbed and non-fenced $10 \times 10$-m plot at each study site at the beginning of the study (May 2006). All these plots were subject to grubbing until the end of the study and, therefore, we assume that boars do not specifically select the sites where they are grubbing. Thus, our randomly chosen non-grubbed fenced plots were sufficient controls to be compared with the respective grubbed plots. Further, a forth plot was established at each site in June 2008. These plots were not disturbed between October 2005 and October 2007, but were freshly grubbed between October 2007 and March 2008. These plots were used to determine if grubbing at different times at different plots would produce the same soil $\mathrm{CO}_{2}$ efflux data as those study plots chosen in 2006 .

Soil sampling and soil $\mathrm{CO}_{2}$ emission measurements

Soil samples were collected twice. The first set of samples was collected at both the grubbed and non-grubbed plots just after plot establishment in early June 2006. The second soil sampling date was 2 years after plot establishment in early June 2008. Each time we randomly selected six locations in each plot to collect mineral soil samples using a 5 -cm-diameter core sampler. Samples were taken at $15-\mathrm{cm}$ depth intervals to a total depth of $45 \mathrm{~cm}$, after removing the litter layer. Soil samples were collected at least $1 \mathrm{~m}$ from the fence to avoid edge effects. Three of the six samples were dried at $65^{\circ} \mathrm{C}$ and fine roots were manually separated from the soil material to obtain fine root biomass (dry weight). The other three samples were immediately put on ice, taken to the laboratory, sieved through a $2-\mathrm{mm}$ sieve and stored for 2 weeks in the cold room at $4^{\circ} \mathrm{C}$. Microbial biomass was then determined using substrate-induced

Table 1 Elevation, soil chemical and soil physical properties of the top $45 \mathrm{~cm}$ of the mineral soil of the six sites under study (data from non-grubbed plots established in May 2006)

\begin{tabular}{|c|c|c|c|c|c|c|c|c|c|}
\hline \multirow[t]{2}{*}{ Site } & \multirow{2}{*}{$\begin{array}{l}\text { Elevation } \\
(\mathrm{m})\end{array}$} & \multirow[t]{2}{*}{$\mathrm{pH}$} & \multirow[t]{2}{*}{$\mathrm{C}(\%)$} & \multirow[t]{2}{*}{$\mathrm{N}(\%)$} & \multirow{2}{*}{$\begin{array}{l}\text { Soil bulk density } \\
\left(\mathrm{g} \mathrm{cm}^{-3}\right)\end{array}$} & \multicolumn{3}{|c|}{ Soil particle size distribution } & \multirow{2}{*}{$\begin{array}{l}\text { Soil texture } \\
\text { class }\end{array}$} \\
\hline & & & & & & Sand $(\%)$ & Silt $(\%)$ & Clay $(\%)$ & \\
\hline 1 & 550 & 3.18 & 2.16 & 0.13 & 1.06 & 72.0 & 18.1 & 9.9 & Sandy loam \\
\hline 2 & 550 & 3.55 & 3.10 & 0.17 & 1.14 & 76.3 & 13.4 & 10.3 & Sandy loam \\
\hline 3 & 560 & 2.92 & 3.00 & 0.14 & 1.01 & 74.6 & 14.4 & 11.0 & Sandy loam \\
\hline 4 & 610 & 2.93 & 4.05 & 0.17 & 1.04 & 69.1 & 20.3 & 10.6 & Sandy loam \\
\hline 5 & 650 & 2.91 & 3.60 & 0.17 & 1.02 & 66.2 & 23.8 & 10.0 & Sandy loam \\
\hline 6 & 670 & 2.81 & 5.05 & 0.22 & 0.83 & 68.2 & 22.5 & 9.3 & Sandy loam \\
\hline
\end{tabular}


method of Anderson and Domsch (1978). Deionized water was added as needed to bring all samples to $60 \%$ waterfilled pore space. The samples where then incubated at room temperature for 10 days prior to analyses to subside spurious microbial activity associated with the sampling disturbance. This incubation period was determined in a preliminary experiment as a minimum before microbial activity declined to a steady state (basal respiration). Microbial biomass was determined using $25 \mathrm{~g}$ of mineral soil (dry weight equivalent) and a glucose concentration of $5 \mathrm{~g} \mathrm{~kg}^{-1}$ soil. $\mathrm{CO}_{2}$ production was analyzed $1-2 \mathrm{~h}$ following the addition using a LI-COR 6200 gas analyzer (LI-COR Biosciences, Lincoln, NE, USA).

In situ soil $\mathrm{CO}_{2}$ emissions were measured with a PP-Systems SRC-1 soil respiration chamber (closed circuit) attached to a PP Systems EGM-4 infrared gas analyzer (PP Systems, Hitchin, Hertfordshire, UK) on five randomly selected locations within each grubbed and non-grubbed plot. For each measurement the soil chamber $(15 \mathrm{~cm}$ high; $10 \mathrm{~cm}$ diameter) was placed on permanently installed PVC collars $(10 \mathrm{~cm}$ diameter) driven $5 \mathrm{~cm}$ deep into the mineral soil at the beginning of the study. The measurements were conducted between 0900 hours and 1700 hours every 6 weeks (expect between November 2006 and March 2007 due to a broken analyzer) starting in June 2006 and ending in June 2008 (total number of measurements $=15$ ). In addition, we measured soil $\mathrm{CO}_{2}$ emissions every 6 weeks on the freshly grubbed plots (installed in June 2008) and nongrubbed plots (installed in May 2006) from July 2008 to May 2009 (no measurements conducted in December and January due to snow on the ground). Freshly germinated plants growing within the PVC collars were removed prior to each of the measurements. We measured soil temperature with a waterproof digital pocket thermometer (Barnstead International, Dubuque, IA, USA) and soil moisture with a Field Scout TDR 100 (time domain reflectometer; Spectrum Technologies, Plainfield, IL, USA) for the 0- to $10-\mathrm{cm}$ mineral soil depth at five random points at each plot during each of the soil $\mathrm{CO}_{2}$ emission measurements.

\section{Statistical analyses}

To investigate whether soil $\mathrm{CO}_{2}$ emissions, soil temperature and moisture differed between the paired grubbed and non-grubbed plots between June 2006 and June 2008 we used a linear mixed model procedure in order to avoid potential pseudoreplication of the data: soil $\mathrm{CO}_{2}$ emission, soil temperature and soil moisture, respectively, were a function of the two fixed-effects treatment (grubbed and non-grubbed) and time and the random-effect site. We also adjusted these models for temporal autocorrelation where necessary. The same linear mixed model approach was used to assess the differences in soil $\mathrm{CO}_{2}$ emission between the originally installed non-grubbed (May 2006) and the freshly grubbed (June 2008) plots. Soil temperature and moisture were highly correlated for both the grubbed and the non-grubbed plots. We therefore tested whether the residuals of this model helped to further explain any of the remaining variance before assessing the relationships between soil moisture or soil temperature (independent variables) and soil $\mathrm{CO}_{2}$ emissions (dependent variable) with linear regression analyses. Differences in fine root and microbial biomass between the grubbed and non-grubbed plots were tested using two-tailed paired $t$ tests for both sampling dates. The $\alpha$-level was 0.05 for all analyses. The normality and homogeneity criteria were met for all data, thus we did not transform our data.

Extrapolation of the effects of boar grubbing on soil $\mathrm{CO}_{2}$ emissions

\section{Percentage of grubbed soil area in the forest stands surrounding our sites}

We established four 200-m-long and 1-cm-wide (width of measuring tape) transects at each of our six sites to determine the percentage of freshly grubbed soil surface area at our sites (from the previous winter until spring). We chose the northern-, eastern-, southern-, and westernmost points of each paired plot as transect starting points. The extent of fresh grubbing along each transect was recorded and the percentage of the transect that was disturbed was calculated. We then averaged the percentages of all four transects per site to obtain an estimate of the total percentage of grubbed forest soil. The inventory was conducted when the study was established in spring 2006 and repeated in spring 2008. From these two inventories we calculated an average percentage of fresh grubbing events for our study sites.

\section{Estimating forest area inhabited by wild boars}

Population counts of wild boars are not available for Switzerland. To estimate wild boar densities we used the average number of wild boars culled during the 2003-2006 hunting seasons (hunting statistics) provided by state agencies for each county or hunting district of the respective state (depending on hunting regimes of the respective state; 2,275 units in total). From these statistics we calculated the number of wild boars culled per $10 \mathrm{~km}^{2}$ for each county or hunting district and entered the information into ArcGIS 9.2. Since our six study sites were located in areas where on average more than ten boars per $10 \mathrm{~km}^{2}$ were culled between 2003 and 2006, we merged all counties/hunting districts for all of Switzerland with ten or more boars culled per $10 \mathrm{~km}^{2}$ to a new layer. We then performed a spatial join of this layer with an existing GIS layer containing information 
on forest cover type (provided by the Swiss Federal Statistical Office 2010): hardwood and mixed-hardwood were defined as potential wild boar habitat, mixed-coniferous and coniferous as non-boar habitat. The resulting joined layer allowed us to calculate the total area of Switzerland that we considered to be potentially inhabited by wild boars at a similar density to our sites ("boar areas"). We assumed that these sites were similarly affected by boars as our sites.

\section{Effect of wild boars on soil $\mathrm{CO}_{2}$ emission at large scales}

To estimate the amount of $\mathrm{CO}_{2}$ released from Swiss forest soils as a result of wild boar grubbing, we calculated the average difference in $\mathrm{CO}_{2}$ emissions between our grubbed and non-grubbed plots using all measurements conducted during the first year of measurement (June 2006 up to and including June 2007). We assumed that the differences in $\mathrm{CO}_{2}$ emissions between grubbed and non-grubbed plots remained constant over the course of the day since the $\mathrm{CO}_{2}$ emissions and temperatures measured showed a strong linear relationship. We then multiplied the potentially grubbed area from the boar areas layer with the percentage grubbed area from the disturbance inventory to estimate the area of grubbed forest soil of the boar areas. The area of grubbed forest soil was then multiplied by the average difference in $\mathrm{CO}_{2}$ emissions between the grubbed and the non-grubbed plots and extrapolated to a yearly basis.

\section{Results}

Grubbing effects on soil properties

In these sandy loam soils, $\mathrm{CO}_{2}$ emissions ranged from 0.06 to $0.52 \mathrm{~g} \mathrm{CO}_{2} \mathrm{~m}^{-2} \mathrm{~h}^{-1}$ on the grubbed plots and from 0.04 to $0.43 \mathrm{~g} \mathrm{CO}_{2} \mathrm{~m}^{-2} \mathrm{~h}^{-1}$ on the non-grubbed plots between June 2006 and June 2008. The rates were significantly higher on the grubbed (average \pm SE for the entire time of study: $\left.0.30 \pm 0.04 \mathrm{~g} \mathrm{CO}_{2} \mathrm{~m}^{-2} \mathrm{~h}^{-1}\right)$ compared to the nongrubbed plots $\left(0.24 \pm 0.04 \mathrm{~g} \mathrm{CO}_{2} \mathrm{~m}^{-2} \mathrm{~h}^{-1}\right)$ throughout the entire time of measurement [no. of measurements taken over time (time) $=15, t=-5.058, P<0.001$; Fig. 1a). On average $0.06 \mathrm{~g} \mathrm{CO}_{2} \mathrm{~m}^{-2} \mathrm{~h}^{-1}$ or $23.1 \%$ more $\mathrm{CO}_{2}$ was released from grubbed plots during these 2 years of
Fig. 1 Soil $\mathrm{CO}_{2}$ emissions, soil temperature and soil moisture measured on grubbed and nongrubbed plots between June 2006 and June 2008: a soil $\mathrm{CO}_{2}$ emissions, b soil temperature, c soil moisture. Data points represent the average \pm SE of all the measurements made at the six grubbed and non-grubbed plots, respectively, during one sampling occasion (time) between June 2006 and June 2008
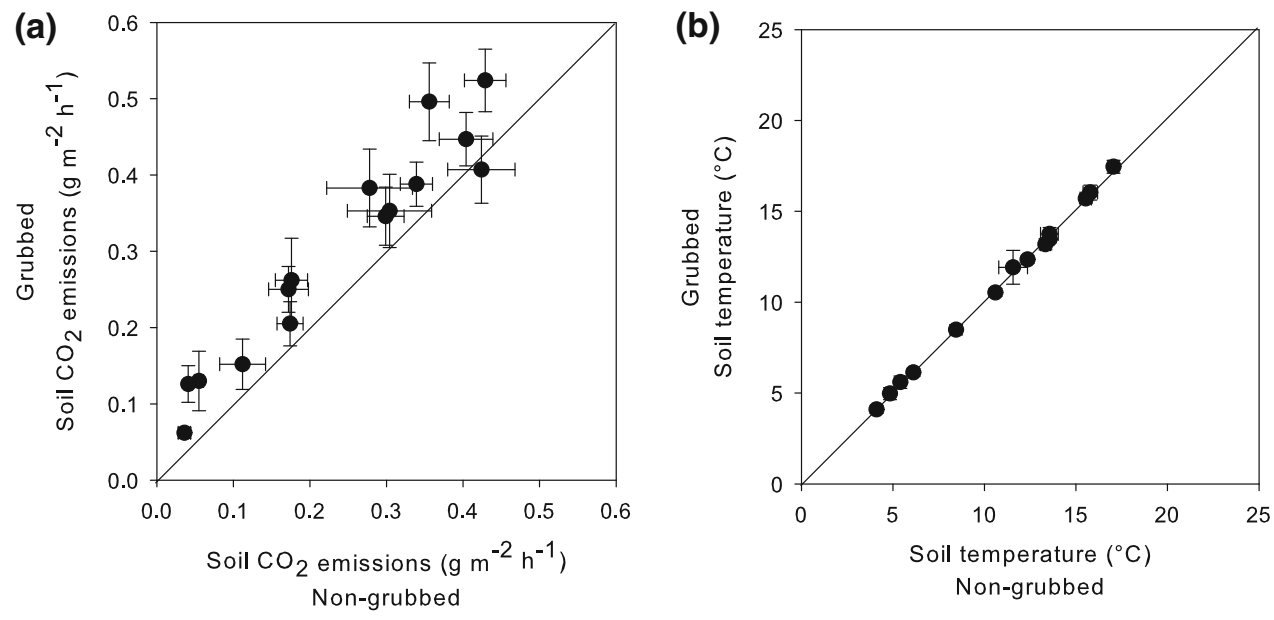
measurement. We also found on average $0.075 \mathrm{~g} \mathrm{CO}_{2}$ $\mathrm{m}^{-2} \mathrm{~h}^{-1}$ higher emissions on the freshly grubbed (winter/ spring 2007/2008) compared to the non-grubbed plots between July 2008 and May 2009 (time $=7, t=-3.043$, $P=0.003$ ). Thus, regardless of the location within the site, grubbing resulted in similar differences in $\mathrm{CO}_{2}$ emissions between the grubbed and non-grubbed plots.

Between June 2006 and June 2008 soil temperature ranged from 4.1 to $17.5^{\circ} \mathrm{C}$ at all the sites, but did not significantly differ between the grubbed (average $10.97 \pm$ $\left.1.18^{\circ} \mathrm{C}\right)$ and the non-grubbed $\left(10.87 \pm 1.17^{\circ} \mathrm{C}\right)$ plots [time $=14$ (one missing measurement due to a broken thermometer), $t=-0.815, P=0.416$; Fig. 1b]. Soil moisture ranged from 7.0 to $24.3 \%(14.1 \pm 0.72 \%)$ on the grubbed and from 6.7 to $26.3 \%(14.9 \pm 0.72 \%)$ on the non-grubbed plots. Soil moisture values were significantly lower for the grubbed compared to non-grubbed plots [time $=14$ (one missing measurement due to broken TDR), $t=2.078$, $P=0.039 ;$ Fig. 1c] .

Soil temperature and moisture were both highly correlated at both the grubbed and the non-grubbed plots with soil temperature having a negative effect on soil moisture (grubbed, $y=-1.105 x+26.238, \quad r^{2}=0.638$, $d f=13, F=21.124, P=0.001$; non-grubbed, $y=-1.154 x+$ 27.479, $r^{2}=0.630, d f=13, F=20.439, P=0.001$, where $x$ is soil temperature and $y$ soil moisture; Fig. 2a). When plotting the residuals of these two models against soil $\mathrm{CO}_{2}$ emissions, it became evident that adding in both soil temperature and moisture would not improve the model (Fig. 2b). Since soil temperature likely is driving soil moisture in the stands under study and not vice versa, we analyzed the relationship between soil temperature and soil $\mathrm{CO}_{2}$ emissions. These variables showed a strong positive relationship for both the grubbed and the non-grubbed plots (grubbed, $y=0.032 x-0.037, r^{2}=0.894, d f=13$, $F=101.448, P<0.001 ;$ non-grubbed, $y=0.030 x-0.082$, $r^{2}=0.830, d f=13, F=58.690, P<0.001$; Fig. 2c). Soil $\mathrm{CO}_{2}$ emissions, soil temperature, and soil moisture all varied significantly over the course of the study $(P$ values $<0.001$ ). Soil $\mathrm{CO}_{2}$ emissions and temperature showed higher values during the summer and lower values during the winter months, while soil moisture showed the opposite pattern (higher in winter, lower in summer). Because our sites were sandy loam textured, the study plots were never sufficiently saturated to result in anaerobic conditions.
Fig. 2 Relationships between soil $\mathrm{CO}_{2}$ emissions, soil temperature and soil moisture measured on grubbed and non-grubbed plots between June 2006 and June 2008: a relationship between soil temperature and moisture, $\mathbf{b}$ relationship between deviation from soil moisturetemperature model and soil $\mathrm{CO}_{2}$ emissions, c relationship between soil temperature and soil $\mathrm{CO}_{2}$ emissions. All regressions are linear. Data points represent the average \pm SE of all the measurements made at the six grubbed and non-grubbed plots, respectively, during one sampling occasion (time) between June 2006 and June 2008
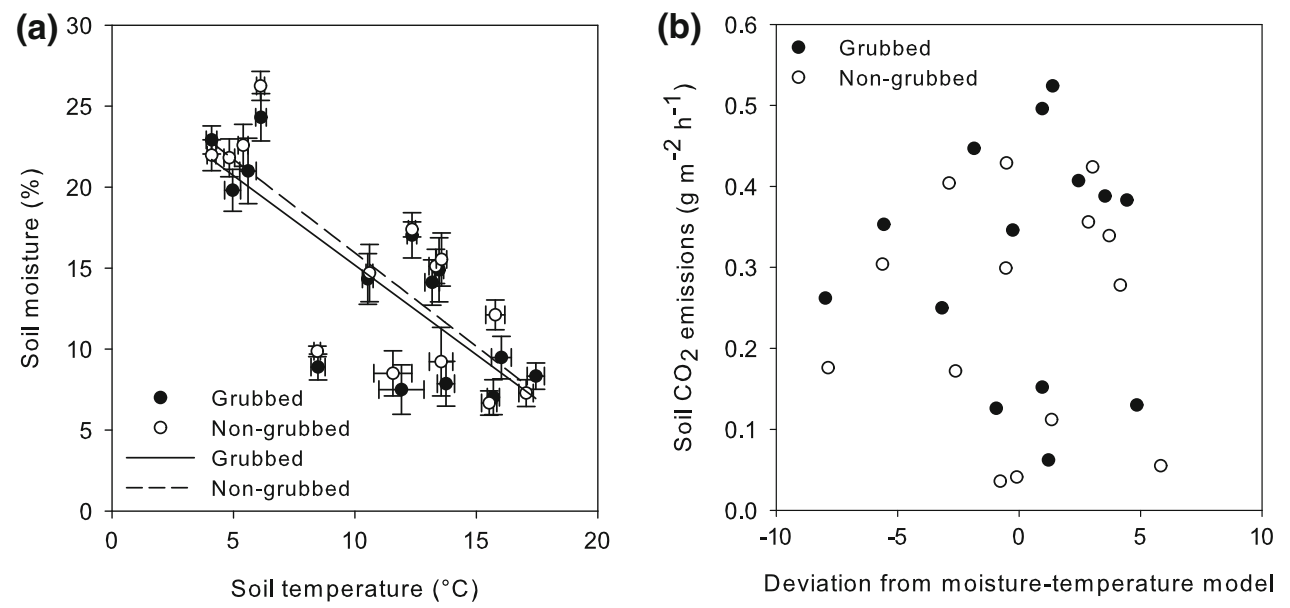
Fine root biomass in the top $45 \mathrm{~cm}$ of the mineral soil averaged $0.006 \pm 0.001 \mathrm{~g} \mathrm{~cm}^{-3}$ soil (dry weight) for grubbed plots in June 2006 and was significantly higher than the $0.004 \pm 0.001 \mathrm{~g} \mathrm{~cm}^{-3}$ soil we found in the nongrubbed plots ( $d f=5, t=4.27, P=0.007$; Fig. 3a). After 2 years, fine root biomass was similar at the grubbed $\left(0.003 \pm 0.0003 \mathrm{~g} \mathrm{~cm}^{-3}\right.$ soil $)$ compared to the non-grubbed plots $\left(0.002 \pm 0.001 \mathrm{~g} \mathrm{~cm}^{-3}\right.$ soil; $d f=5, t=0.39, P=0.39$; Fig. 3a). A similar pattern was found for microbial biomass of the top $45 \mathrm{~cm}$ of the mineral soil: the values were significantly higher on the grubbed compared to the non-grubbed plots $(d f=5, \quad t=3.10, \quad P=0.03), \quad$ averaging $822.6 \pm$ $94.2 \mathrm{mg} \mathrm{C} \mathrm{kg}^{-1}$ soil (grubbed) and $541.0 \pm 0.1 \mathrm{mg} \mathrm{C} \mathrm{kg}^{-1}$ soil (non-grubbed), respectively, at the beginning of the study in June 2006 (Fig. 3b). In June 2008 microbial biomass at the grubbed plots $\left(1,235.2 \pm 154.2 \mathrm{mg} \mathrm{C} \mathrm{kg}^{-1}\right.$ soil $)$ was no longer significantly different from that at the nongrubbed plots $\left(841.5 \pm 86.7 \mathrm{mg} \mathrm{C} \mathrm{kg}^{-1}\right.$ soil; $d f=5, t=$ $1.85, P=0.12$; Fig. 3b). Our findings indicate that grubbing by wild boars had a long-lasting effect on soil $\mathrm{CO}_{2}$ emissions, significantly increasing the small-scale spatial heterogeneity of this parameter. Fine root and microbial biomass were only significantly higher after the initial grubbing event. The reason for not finding significant differences in these two parameters 2 years after the initial grubbing event may be due to: (1) time since grubbing (incorporation of the litter layer into the mineral soil long time ago), (2) withinplot variability of both fine roots and microbial biomass, and/or (3) the small number of replicate paired plots $(n=6$; see also Fig. 3).

Extrapolation of the effects of boar grubbing on soil $\mathrm{CO}_{2}$ emissions

The percentage of disturbed forest soil averaged $53.8 \%$ in 2006 and $27.2 \%$ in 2008 at our sites. We used the 2006 values as maximum, the 2008 values as minimum and average of both $(40.5 \%)$ for our calculations, resulting in three different disturbance scenarios. The total area of Switzerland with densities of culled boars greater than ten animals per $10 \mathrm{~km}^{2}$ and covered by hardwood or mixed hardwood forests was $410 \mathrm{~km}^{2}$ (Fig. 4), which corresponds to roughly $1 \%$ of Switzerland's surface area. Based on these assumptions, we calculated the quantity of $\mathrm{CO}_{2}$ released given the different disturbance conditions. Assuming $53.8 \%$ of the area to be disturbed (maximum), $98,454.74 \mathrm{t}$ of $\mathrm{CO}_{2}$ per year in addition to the regular soil $\mathrm{CO}_{2}$ emissions would be released by grubbing. If we assume $40.5 \%$ (average) of the forest soil to be disturbed, then the additional emissions would amount to 740,92.91 t CO year $^{-1}$, whereas 49,731.10 t CO year $^{-1}$ would be released given the minimum percentage $(27.2 \%)$ of soil disturbance.

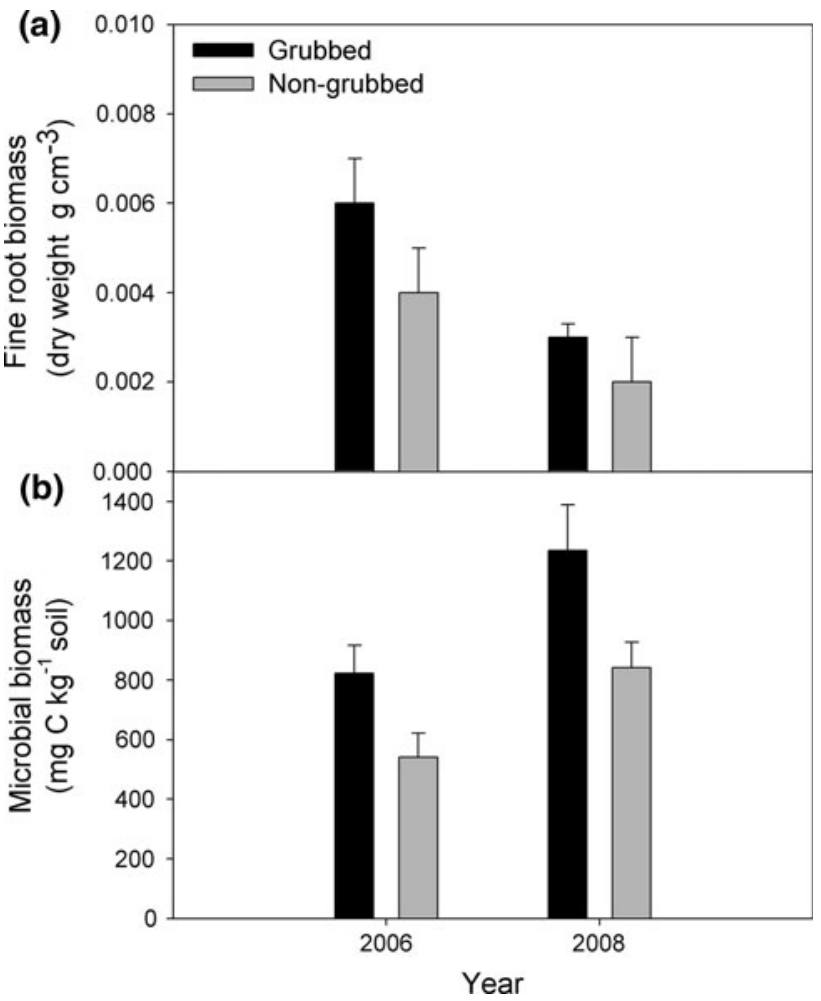

Fig. 3 Fine root and microbial biomass on grubbed and non-grubbed plots measured in June 2006 and June 2008 ( $n=6$ for all graphs): a fine root biomass for the top $45 \mathrm{~cm}$ of the mineral soil, $\mathbf{b}$ microbial biomass for the top $45 \mathrm{~cm}$ of the mineral soil. Data represent averages \pm SEs of all sites

\section{Discussion}

Grubbing effects on soil $\mathrm{CO}_{2}$ emissions

Our results showed that grubbing by wild boars had a longlasting effect on soil $\mathrm{CO}_{2}$ emissions as we measured significantly higher emission rates on the grubbed compared to the non-grubbed plots throughout the study. We are not aware of any other study that has measured the effects of grubbing by wild boars or another omnivorous vertebrates on soil $\mathrm{CO}_{2}$ emissions. However, similar as grubbing by boars, soil disturbance by pink-footed geese searching for belowground plant parts early in the season was found to have a strong effect on $\mathrm{C}$ dynamics in a tundra ecosystem reducing both photosynthesis and ecosystem respiration (van der Wal et al. 2007). Unfortunately, soil $\mathrm{CO}_{2}$ emissions were not measured in this study, making a comparison difficult.

Forest management practices (site preparation) that mix the surface litter layer with the mineral soil also seem to have a similar effect on soil $\mathrm{CO}_{2}$ emissions as grubbing by wild boars. For example, Mallik and $\mathrm{Hu}$ (1997) found over $50 \%$ higher soil $\mathrm{CO}_{2}$ emissions on clear-cut plots when 


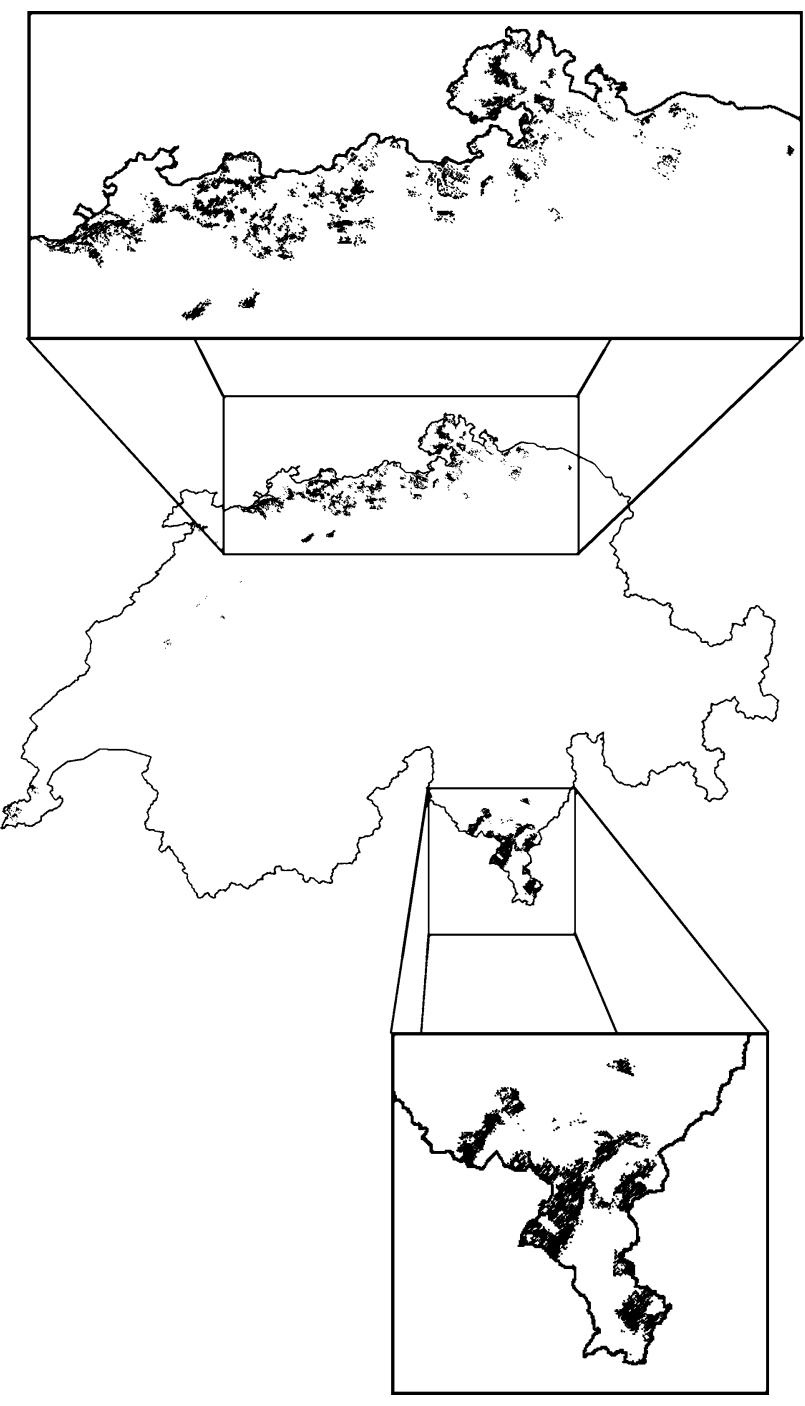

Fig. 4 Areas within Switzerland where on average (2003-2006) more than ten boars have been culled per $10 \mathrm{~km}^{2}$ and where the forest cover type was classified as hardwood or mixed hardwood forest by the Swiss Federal Statistical Office (2010). Excerpts show the northernand southernmost parts of Switzerland, where the model predictions were highest

they mixed the soil to a depth of $20 \mathrm{~cm}$ compared to the uncut control stands. Similarly, Pumpanen et al. (2004) reported $20 \%$ higher soil $\mathrm{CO}_{2}$ emissions from soils of clearcut coniferous stands where the mineral soil and litter layer were mixed (mounding) compared to the clear-cut only plots. In addition, they found $32 \%$ higher soil $\mathrm{CO}_{2}$ emission values on the clear-cut mounded plots compared to plots established in uncut control stands. However, the studies that assessed the effect of site preparation on soil $\mathrm{CO}_{2}$ emissions have looked at clear-cut sites. These sites would likely respond somewhat differently than our sites grubbed by boars where no clear-cutting occurred and forest cover was maintained. Overall, the magnitude and seasonal variability of our soil $\mathrm{CO}_{2}$ emission rates at the non-grubbed plots lay within the ranges of what has been reported from other hardwood forest ecosystems in Europe (e.g., Jonard et al. 2007; Knohl et al. 2008).

We can think of three explanations for the differences in $\mathrm{CO}_{2}$ emissions that were detected between the grubbed and non-grubbed plots in our study. Moldrup et al. (2004) modeled soil gas diffusion as a function of air-filled porosity, total porosity and macro-porosity and demonstrated that drier soils have higher diffusion rates compared to wetter soils. Thus, it is possible that the decrease in soil moisture that we detected as a result of grubbing was directly responsible for the increases in soil $\mathrm{CO}_{2}$ emissions. It also has been shown that a soil with decreased soil porosity, for example as a result of soil compaction, has lower diffusion rates than non-compacted soils (e.g., Conlin and van den Driessche 2000; Shestak and Busse 2005). If the opposite were true for soils that are "plowed"-i.e., that soils with higher porosity have higher gas diffusion rates-then our higher soil $\mathrm{CO}_{2}$ fluxes observed within the grubbed plots could also be related to increased soil porosity. A third explanation for our results could be that higher auto- and heterotrophic respiration, as a result of soil disturbance (bioturbation), were responsible for our findings, which we will discuss in detail in the following:

1. Grubbing by wild boars is known to incorporate the litter layer into the mineral soil (e.g., Singer et al. 1984; Brownlow 1994), which increases the amount of C available for the decomposer food web. Thus, soil nutrient mobility, availability and mineralization rates and the amount of roots and microbes could be affected. Several studies have investigated soil $\mathrm{C}$ and nutrient availability and/or mineralization on grubbed and non-grubbed soil. They have found positive (Singer et al. 1984), neutral (Groot Bruinderink and Hazebroek 1996; Moody and Jones 2000; Cushman et al. 2004; Mohr et al. 2005; Tierney and Cushman 2006) or negative (Mohr and Topp 2001) effects of wild boar grubbing in oak/oak-beech forests and grassland ecosystems as well as positive effects of grizzly bear digging on $\mathrm{NH}_{4}{ }^{+}-\mathrm{N}$ and $\mathrm{NO}_{3}{ }^{-}-\mathrm{N}$ availability in subalpine meadows (Tardiff and Stanford 1998). Two of the studies listed above also provided data on microbial biomass (Mohr and Topp 2001; Mohr et al. 2005) showing lower values for grubbed compared to nongrubbed loamy soils of dry oak forests located in the western part of Germany. Potential reasons for these highly variable and in some cases contrasting results to our own findings could be related to differences in ecosystem properties (e.g., soil physical, chemical and biological properties, vegetation type), boar densities, or climatic conditions (air temperature, precipitation) among the studies. 
2. Besides integrating the litter into the mineral soil and increasing soil $\mathrm{C}$ available for microbes, grubbing by wild boars could have led to higher microbial biomass by decreasing the size of soil aggregates. Such decreases have been shown to occur after tilling and result in higher amounts of inter-aggregate unprotected light fraction organic matter, which directly favors microbial growth (Grandy and Robertson 2006a, b). Similarly, Goebel et al. (2009) showed in a laboratory trial with soils originating from both agricultural land and forests that intact soil macro-aggregates released less $\mathrm{CO}_{2}$ than crushed material. Unfortunately, we could not find any study that assessed how wild boars or other animals affect soil aggregate size when grubbing. However, it is likely that they would have a similar effect to a tractor plowing the soil.

3. Root growth has been shown to be higher on soils with lower bulk densities, compared to soils with higher bulk densities (Siegel-Issem et al. 2005). Grubbing by wild boars leads to decreases in soil bulk density because of the mixing of litter with the mineral soil (Singer et al. 1984) as we also found at our sites (unpublished data). Such decreases in bulk density could directly favor root growth. In addition, the changes in bulk density could also alter the composition of the soil fauna. Such compositional changes could affect root herbivory rates and therefore root growth. Alternatively, alterations of the soil fauna could affect the availability of soil nutrients and indirectly change root growth. However, we are not aware of any study that conducted such an investigation. Microbial biomass, in contrast to root growth, has generally been suggested to be rather robust to changes in soil bulk density (e.g., Shestak and Busse 2005, Busse et al. 2006), thus microbial biomass probably was not altered as a result of decreased bulk density due to grubbing by wild boars.

4. Consumption of soil-inhabiting vertebrates and invertebrates by boars (e.g., Genov 1981; Fournier-Chambrillon et al. 1995; Baubet et al. 2003) could affect the composition and abundance of root herbivores, bacterial feeders, other soil animals or fungi and therefore alter fine root and microbial biomass. For example, Mohr et al. (2005) reported significantly lower numbers of saprophagous and predatory soil arthropods as well as isopods, while the species numbers of the Aranaea (spiders) were not affected in plots subject to simulated grubbing in oak stands in Germany. Mohr and Topp (2001) found decreases in numbers of soil arthropods where wild boars and red deer (Cervus elaphus L.) had disturbed the soil. Similar to these results, wild pigs inhabiting Hawaiian forests significantly reduced both the abundance and biomass of soil micro-arthropods.
However, they had no effect on nematodes and larger soil invertebrate animals (Vtorov 1993). Even though there is strong evidence of shifts in the composition and abundance of soil-inhabiting animals following grubbing by large mammals, there is no information available on how such changes affect soil microbial or root biomass.

5. It is possible that wild boars deposit considerable amounts of dung and urine while searching the soil for forage. These additions of readily available nutrients to the forest soil could result-at least temporarily-in increased fine root and microbial biomass, and subsequent higher soil $\mathrm{CO}_{2}$ emission rates where boars have grubbed. Such increases in root and microbial biomass have been studied in ecosystems where large herbivores occur at high densities (e.g., Frank and Evans 1997; van der Wal et al. 2004). Whether the same effects would be found in systems inhabited by wild boars, which generally occur in much lower densities compared to large herbivores, remains to be studied.

Based on all the evidence we found in the field we feel we can confidently assume that boars did grub randomly in the forests under study and that our randomly chosen non-grubbed fenced plots were sufficient controls to be compared with the respective grubbed plots. However, we cannot rule out that some of the differences in soil or plant properties that we measured already existed prior to grubbing. Unfortunately, such differences could not be accounted for as it is not possible to predict where the boars are going to grub and therefore "pre-treatment" sampling was not possible.

Extrapolation of the effects of boar grubbing on soil $\mathrm{CO}_{2}$ emissions

The percentage of forest soil disturbance caused by wild boars at our sites was approximately within the range reported by other studies conducted in hardwood stands. For example, Howe et al. (1981) found that roughly $80 \%$ of the surface area was disturbed in a beech forest in Tennessee, USA and Welander (2000) reported boar rooting frequencies ranging from $4 \%$ in dry soils to $75 \%$ in mesic soils in deciduous forest stands in Sweden. In contrast, less than $10 \%$ of the surface area was disturbed by grubbing in a montane rain forest in Hawaii, USA (Ralph and Maxwell 1984), or in Eucalyptus stands in Australia (Hone 1988).

When using the average percentage of freshly disturbed forest soils measured in our stands together with the approximation of boar densities and forest cover, we calculated that grubbing by wild boars would result in a release of 49,731.10-98,454.74 $\mathrm{t}$ additional $\mathrm{CO}_{2}$ per year in Switzerland. These numbers likely underestimate the total 
effect boars have on forest soil $\mathrm{CO}_{2}$ emissions as they neither account for patches that were grubbed in previous years nor do they consider sites inhabited by fewer boars compared to our sites. Overall, they only represent between 0.64 and $1.26 \%$ of the soil $\mathrm{CO}_{2}$ emissions estimated for Swiss hardwood and mixed-hardwood forest soils $\left(7,802,006.40 \mathrm{tCO}_{2}\right.$ year) using our average soil $\mathrm{CO}_{2}$ emission rate measured at the non-grubbed plots $\left(0.24 \mathrm{~g} \mathrm{CO}_{2}\right.$ $\mathrm{m}^{-2} \mathrm{~h}^{-1}$ ) and the estimated total of $3,711 \mathrm{~km}^{2}$ Swiss hardwood/mixed hardwood forest soils based on the National Forest Inventory (Brassel and Brändli 1999). However, even if we were able to include older grubbing events as well as all boar-inhabited areas into our model, the contribution of boars grubbing to the total amount of $\mathrm{CO}_{2}$ released from Swiss hardwood/mixed hardwood soils likely would remain rather negligible given current population sizes. Nevertheless, the contributions could increase if the animals increase in population size and if they extend their range within the country. To date they are confined to the northern and southernmost parts of Switzerland (cf. Hausser 1995) due to highways and mountain ranges that act as barriers. Yet, the animals are expected to overcome these obstacles eventually, thus, their impact on forest soil $\mathrm{CO}_{2}$ emissions might increase in the future. Nevertheless, it also is possible that the $\mathrm{C}$ source-sink relationships of the forests the boars inhabit will remain unaltered due to increased tree growth on soils where they have grubbed. For example, Lacki and Lancia (1986) reported a positive relationship between shoot elongation of American beech and the rooting of boars, which indicates that the amount of $\mathrm{C}$ lost from the soil through grubbing could be neutralized by increased photosynthetic uptake of $\mathrm{CO}_{2}$ by the trees. Further investigations will show whether this would be the case at our study sites.

Acknowledgments We thank Dieter Trummer, Lieven Dekoninck, Florian Risch, Barbara Moser and Ulrich Wasem for their help with establishing the fences and Dieter Trummer, Manuel Lingg and Verena Hechinger for their help during field work. We are grateful to Alice Ratcliff and Joanne Tirocke for analyzing the soil samples in the laboratory, to ETH statistical consulting services, Christof Bigler and several other people for their statistical advice. Our thanks also go to the local foresters and hunting organizations for their support of our study and granted access to our sites. We thank the authorities of the states of Switzerland for providing the hunting statistics. In addition, we thank the anonymous reviewers for their helpful comments on the manuscript, and the Vegetation and Soil sub-project of the Swiss National Forest Inventory for funding this study. The present study was conducted in compliance with the current laws of Switzerland.

\section{References}

Anderson JPE, Domsch KH (1978) A physiological method for the quantitative measurement of microbial biomass in soil. Soil Biol Biochem 10:215-221
Baber DW, Coblentz BE (1987) Diet, nutrition and conception in feral pigs on Santa Catalina Island. J Wildl Manage 51:306-317

Bardgett RD, Wardle DA (2003) Herbivore mediated linkages between aboveground and belowground communities. Ecology $84: 2258-2268$

Baubet E, Ropert-Coudert Y, Brandt S (2003) Seasonal and annual variations in earthworm consumption by wild boar (Sus scrofa scrofa L.). Wildl Res 30:179-186

Brassel P, Brändli UB (1999) Schweizerisches Landesforstinventar: Ergebnisse der Zweitaufnahme 1993-1995. Haupt, Bern

Bratton SP, Harmon ME, White PS (1982) Patterns of European wild boar rooting in the western Great Smoky Mountains. Castanea 47:230-242

Bremer DJ, Ham JM (2002) Measurement and modeling of soil $\mathrm{CO}_{2}$ flux in a temperate grassland under mowed and burned regimes. Ecol Appl 12:1318-1328

Bremer DJ, Ham JM, Owensby CE, Knapp AK (1998) Responses of soil respiration to clipping and grazing in a tallgrass prairie. J Environ Qual 27:1539-1548

Brownlow MJC (1994) Towards a framework of understanding for the integration of forestry with domestic pig (Sus scrofa domestica) and European wild boar (Sus scrofa scrofa) husbandry in the United Kingdom. Forestry 67:189-217

Busse MD, Beattie SE, Powers RF, Sanchez FG, Tiarks AE (2006) Microbial community responses in forest mineral soil to compaction, organic mater removal and vegetation control. Can J For Res 36:577-588

Carter DO, Yellowlees D, Tibbett M (2007) Cadaver decomposition in terrestrial ecosystems. Naturwissenschaften 94:12-24

Conlin TSS, van den Driessche R (2000) Response of soil $\mathrm{CO}_{2}$ and $\mathrm{O}_{2}$ concentrations to forest soil compaction at the long-term soil productivity sites in central British Columbia. Can J For Res 80:625632

Cushman JH, Tierney TA, Hinds JM (2004) Variable effects of feral pig disturbances on native and exotic plants in a California grassland. Ecol Appl 14:1746-1756

Epstein HE, Burke IC, Lauenroth WK (2002) Regional patterns of decomposition and primary production rates in the U.S. Great Plains. Ecology 83:320-327

Feichtner B (1998) Ursachen der Streckenschwankungen beim Schwarzwild im Saarland. Z Jagdwiss 44:140-150

Fornara DA, Du Toit JT (2008) Browsing-induced effects on leaf litter quality and decomposition in a southern African savanna. Ecosystems 11:238-249

Fournier-Chambrillon C, Maillard D, Fournier P (1995) Diet of the wild boar (Sus scrofa L.) inhabiting the Montpellier Garrigue. Ibex 3:174-179

Frank DA, Evans RD (1997) Effects of native grazers on grassland N cycling in Yellowstone National Park. Ecology 78:2238-2248

Gabet EJ, Reichmann OJ, Seabloom EW (2003) The effect of bioturbation on soil processes and sediment transport. Annu Rev Earth Planet Sci 31:249-273

Geisser H, Reyer HU (2005) The influence of food and temperature on population density of wild boar Sus scrofa in the Thurgau (Switzerland). J Zool 267:89-96

Genov P (1981) Food composition of wild boar in north-eastern and western Poland. Acta Theriol 26:185-205

Goebel MO, Woche SK, Bachmann J (2009) Do soil aggregates really protect encapsulated organic matter against microbial decomposition? Biologia 64:443-448

Grandy AS, Robertson GP (2006a) Aggregation and organic matter protections following tillage of previously uncultivated soil. Soil Sci Soc Am J 70:1398-1406

Grandy AS, Robertson GP (2006b) Initial cultivation of a temperateregion soil immediately accelerates aggregate turnover and $\mathrm{CO}_{2}$ and $\mathrm{N}_{2} \mathrm{O}$ fluxes. Global Chang Biol 12:1507-1520 
Groot Bruinderink GWTA, Hazebroek E (1996) Wild boar (Sus scrofa scrofa $\mathrm{L}$.) rooting and forest regeneration on podzolic soils in the Netherlands. For Ecol Manag 88:71-80

Hausser J (1995) Säugetiere der Schweiz: Verbreitung, Biologie, Oekologie. Birkhäuser, Basel

Hebeisen C, Fattebert J, Baubet E, Fischer C (2007) Estimating wild boar (Sus scrofa) abundance and density using capture-resights in Canton of Geneva, Switzerland. Eur J Wildl Res 54(3):391401

Hespeler B (2004) Schwarzwild heute. BLV, München

Hone $\mathbf{J}$ (1988) Feral pig rooting in a mountain forest and woodland: distribution, abundance and relationship with environmental variables. Aust J Ecol 13:393-400

Howe TD, Bratton SP (1976) Winter rooting activity of the European wild boar in the Great Smoky Mountains National Park. Castanea 41:256-264

Howe TD, Singer FJ, Ackermann BB (1981) Forage relationship of European wild boar invading northern hardwood forest. J Wildl Manag 45:748-754

Imeson A (1977) Splash erosion, animal activity and sediment supply in a small forested Luxemburg catchment. Earth Surf Process Landf 2:153-160

Jefferies RL, Klein DR, Shaver GR (1994) Vertebrate herbivores and northern plant communities: reciprocal influences and processes. Oikos 71:193-206

Jia B, Zhou G, Wand F, Wang Y, Weng E (2007) Effects of grazing on soil respiration of Lymus chinensis steppe. Clim Chang 82:211223

Johnson LC, Matchett JR (2001) Fire and grazing regulate belowground processes in tallgrass prairie. Ecology 82:3377-3389

Jonard M, Andre F, Jonard F, Mouton N, Proces P, Ponette Q (2007) Soil carbon dioxide efflux in pure and mixed stands of oak and beech. Ann For Sci 64:141-150

Keller W, Wohlgemuth T, Kuhn N, Schütz M, Wildi O (1998) Waldgesellschaften der Schweiz auf floristischer Grundlage. Mitt Eidgenöss Forschanst Wald Schnee Landsch 73:93-357

Kirschbaum MUF (1995) The temperature dependence of soil organic matter decomposition, and the effect of global warming on soil organic C storage. Soil Biol Biochem 27:753-760

Knapp AK, Conrad SL, Blair JM (1998) Determinants of soil $\mathrm{CO}_{2}$ flux from a sub-humid grassland: effect of fire and fire history. Ecol Appl 8:760-770

Knohl A, Soe ARB, Kutsch WL, Göckede M, Buchmann N (2008) Representative estimates of soil and ecosystem respiration in an old beech forest. Plant Soil 302:189-202

Kotanen PM (1995) Responses of vegetation to changing regime of disturbance: effects of feral pigs in a Californian coastal prairie. Ecography 18:190-199

Krüger T ((1998)) Entwicklung der Jagdstrecken des Schwarzwildes (Sus scrofa L. 1758) und möglicher Einflussfaktoren im heutigen Freistaat Sachsen. Z Jagdwiss 4:151-166

Lacki MJ, Lancia RA (1986) Effects of wild pigs on beech growth in Great Smoky Mountains National Park. J Wildl Manage 50:655659

Lomander A, Katterer TA, Andrean O (1998) Carbon dioxide evolution from top- and subsoil as affected by moisture and constant and fluctuating temperature. Soil Biol Biochem 30:2017-2022

Mallik AU, Hu D (1997) Soil respiration following site preparation treatments in boreal mixed wood forest. For Ecol Manage 97:265-275

Melis C, Szafrańska PA, Jędrzejewska B, Bartoń K (2006) Biogeographical variation in the population density of wild boar (Sus scrofa) in western Eurasia. J Biogeogr 33:803-811

MeteoSchweiz (2008) http://www.meteoschweiz.admin.ch/web/de/ klima/klimaentwicklung/homogene_reihen.html
Mohr D, Topp W (2001) Forest soil degradation in slopes of the low mountain range of Central Europe-do deer matter? Forstw Cbl 120:220-230

Mohr D, Cohnstaedt LW, Topp W (2005) Wild boar and red deer affect soil nutrients and soil biota in steep oak stands of the Eifel. Soil Biol Biochem 37:693-700

Moldrup P, Olesen T, Yoshikawa S, Komatsu T, Tolston DE (2004) Three-porosity model for predicting the gas diffusion coefficient in undisturbed soil. Soil Sci Soc Am J 68:750-759

Moody A, Jones JA (2000) Soil response to canopy position and feral pig disturbance beneath Quercus agrifolia on Santa Cruz Island, California. Appl Soil Ecol 14:269-281

Morris JT, Jensen A (1998) The carbon balance of grazed and nongrazed Spartina anglica saltmarshes at Skallingen, Denmark. J Ecol 86:229-242

Owensby CE, Ham JM, Auen LM (2006) Fluxes of $\mathrm{CO}_{2}$ from grazed and ungrazed tallgrass prairie. Rangel Ecol Manage 59:111-127

Pastor J, Cohen Y, Hobbs NT (2006) The roles of large herbivores in ecosystem nutrient cycling. In: Danell K, Bergström R, Duncan P, Pastor J (eds) Large herbivore ecology ecosystem dynamics and conservation. Cambridge University Press, Cambridge, pp 289325

Pumpanen J, Westman CJ, Ilvesniemi $\mathrm{H}$ (2004) Soil $\mathrm{CO}_{2}$ efflux from a podzolic forest soil before and after forest clear-cutting and site preparation. Boreal Environ Res 9:199-212

Ralph CJ, Maxwell BD (1984) Relative effects of human and feral hog disturbance on a wet forest in Hawaii. Biol Conserv 30:291-303

Risch AC, Frank DA (2006) Carbon dioxide fluxes in a spatially and temporally heterogeneous temperate grassland. Oecologia 147:291-302

Rochette P, Angers DA, Cote D (2000) Soil carbon and nitrogen dynamics following application of pig slurry for the 19th consecutive year. I. Carbon dioxide fluxes and microbial biomass carbon. Soil Sci Soc Am J 64:1389-1395

Russell RE, Detling JK (2003) Grasshoppers (Orthoptera: Acrididae) and black-tailed prairie dogs (Sciuridae: Cynomys ludovicianus (Ord)): associations between two rangeland herbivores. J Kansas Entomol Soc 76:578-587

Schley L, Krier A, Wagner M, Roper TJ (1998) Changes in the wild boar Sus scrofa population in Luxembourg during the period 1946 to 1996. Bulletin de la société des Naturalistes Luxembourgeois 99:77-85

Schulze ED (2006) Biological control of the terrestrial carbon sink. Biogeosciences 3:147-166

Shestak CJ, Busse MD (2005) Compaction alters physical but not biological indices of forest health. Soil Sci Soc Am J 69:236-246

Siegel-Issem CM, Burger JA, Powers RF, Ponder F, Patterson SC (2005) Seedling root growth as a function of soil density and water content. Soil Sci Soc Am J 69:215-226

Sierra C (2001) The feral pig (Sus scrofa, Suidae) in Cocos Island, Costa Rica: rootings, soil alterations and erosion. Rev Biol Trop 49:1159-1170

Singer FJ, Swank WT, Clebsch EEC (1984) Effects of wild pig rooting in a deciduous forest. J Wildl Manage 48:464-473

Swiss Federal Statistical Office (2010) http://www.bfs.admin.ch/bfs/ portal/de/index/dienstleistungen/geostat/datenbeschreibung/waldmischungsgrad.html

Tardiff SE, Stanford JA (1998) Grizzly bear digging: effects on subalpine meadow plants in relation to mineral nitrogen availability. Ecology 79:2219-2228

Taylor RB, Hellgren EC, Gabor TM, Ilse LM (1998) Reproduction of feral pigs in southern Texas. J Mammal 79:1325-1331

Tierney TA, Cushman JH (2006) Temporal changes in native and exotic vegetation and soil characteristics following disturbance by feral pigs in a California grassland. Biol Invasions 8:1073-1089 
Van der Wal R, Bardgett RD, Harrison KA, Stien A (2004) Vertebrate herbivores and ecosystem control: cascading effects of feces on tundra ecosystems. Ecography 27:242-252

Van der Wal R, Sjorgertsen S, Wooding SJ, Cooper EJ, Jonsdottir IS, Kuipers D, Fox TAD, Huiskes AD (2007) Spring feeding by pinkfooted geese reduces carbon stocks and sink strength in tundra ecosystems. Glob Chang Biol 13:539-545

Vtorov IP (1993) Feral pig removal: effects on soil micro-arthropods in a Hawaiian rain forest. J Wildl Manage 57:875-880
Wardle DA, Bardgett RD, Klironomos JN, Setälä H, van der Putten WH, Wall DH (2004) Ecological linkages between aboveground and belowground biota. Science 304:1629-1633

Welander J (2000) Spatial and temporal dynamics of wild boar (Sus scrofa) rooting in a mosaic landscape. J Zool 252:263-271

Wood GW, Roark DN (1980) Food habits of feral hogs in coastal South Carolina. J Wildl Manage 44:506-511 